\title{
Arrangement, Description and Presentation of the Nancy Newhall Negative Collection at George Eastman House
}

by

Jessica W. Johnston, BA, Brooks Institute of Photography, 2002

\author{
A Thesis Project \\ Presented to Ryerson University \\ in partial fulfillment of the \\ requirements for the degree of \\ Master of Arts \\ in the program of \\ Photographic Preservation and Collections Management
}

Toronto, Ontario, Canada, 2006

CJessica W. Johnston 
UMI Number: EC53861

\section{INFORMATION TO USERS}

The quality of this reproduction is dependent upon the quality of the copy submitted. Broken or indistinct print, colored or poor quality illustrations and photographs, print bleed-through, substandard margins, and improper alignment can adversely affect reproduction.

In the unlikely event that the author did not send a complete manuscript and there are missing pages, these will be noted. Also, if unauthorized copyright material had to be removed, a note will indicate the deletion.

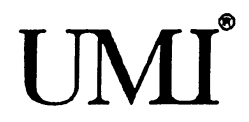

UMI Microform EC53861

Copyright 2009 by ProQuest LLC

All rights reserved. This microform edition is protected against unauthorized copying under Title 17, United States Code.

ProQuest LLC

789 East Eisenhower Parkway

P.O. Box 1346

Ann Arbor, Ml 48106-1346 
I hereby declare that I am the sole author of this thesis.

I authorize Ryerson University George Eastman House International Museum of Photography and Film to lend this thesis to other institutions or individuals for the purpose of scholarly research.

I further authorize Ryerson University George Eastman House International Museum of Photography and Film to reproduce this thesis by photocopying or by other means, in total or in part, at the request of other institutions or individuals for the purpose of scholarly research.

1 
Arrangement, Description and Presentation of

The Nancy Newhall Negative Collection at

George Eastman House

Master of Arts, 2006

Jessica W. Johnston

Photographic Preservation and Collections Management

Ryerson University/George Eastman House

\begin{abstract}
This thesis project, focusing on the arrangement, description and cataloging of the Nancy Newhall negative collection at George Eastman House, was undertaken to provide accessibility to the collection for research purposes. The paper includes the following information: (1) A short biography of the life of Nancy Newhall and a chronology of her life outlining major events and achievements; and (2) an outline and discussion of the arrangement, rehousing, digitization, and cataloging of the collection.
\end{abstract}


Table of Contents

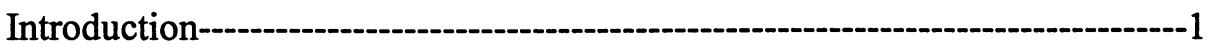

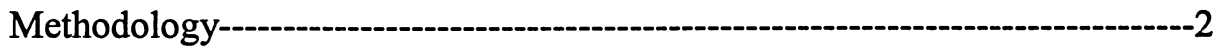

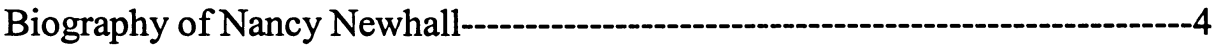

Scope and Content---11

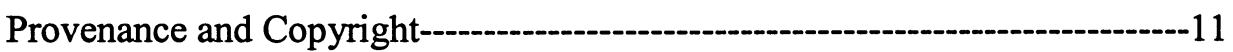

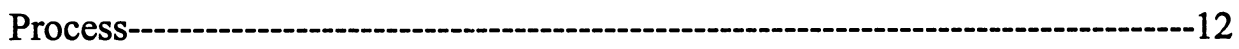

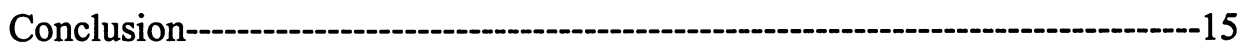

Appendix A-Chronology of Nancy Newhall's Life---

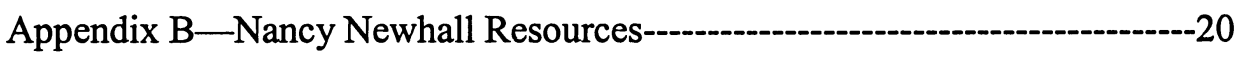

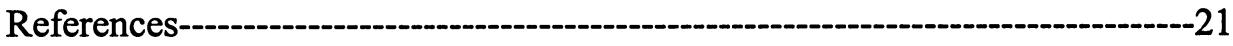




\section{Introduction}

Nancy Newhall (1908-1974) made a significant contribution to the field of photographic history during its formative years in the United States, publishing extensively on the subject. Among other accomplishments, Newhall held the position of Acting Curator of Photography at the Museum of Modern Art (MoMA) from 1942 to 1945, collaborated with Ansel Adams and Paul Strand on several book projects, and published a book on the photographs of P.H. Emerson. In addition to these scholarly pursuits, Newhall was herself an accomplished photographer; using the medium that defined her life, she documented travels, friends, and surroundings.

In 1995 the estate of Beaumont Newhall gifted Nancy Newhall's negatives to George Eastman House International Museum of Photography and Film. This collection of 556 negatives is an invaluable resource to researchers interested in the life and work of Nancy Newhall and the lives of persons pictured in her images. The negatives were inventoried when first acquired by Eastman House in 1995. Since that time, however, the collection has remained unprocessed. Because of the importance of Nancy Newhall and her close association with George Eastman House, Beaumont Newhall, Ansel Adams, the Weston family, and other prominent figures in photographic history, further attention to the Newhall negatives is warranted.

This thesis project, focusing on the arrangement, description and digitization of the Nancy Newhall negatives, was undertaken to provide accessibility to the collection for research purposes. The process involved the following steps: (1) Information on the life and work of Nancy Newhall was collected to prepare a biography and chronology of her life as a writer and photographic historian; (2) the negatives were rehoused and arranged; (3) the negatives and original housings containing Newhall's inscriptions were digitized; (4) the negatives were catalogued in the museum's collection management system, The Museum System (TMS); (5) digital surrogates of the images and housings were created and added to the catalog records; and (6) in fulfillment of the thesis requirements, this paper was prepared to document the project and summarize results. 


\section{Methodology}

In order to arrange and catalogue the Nancy Newhall Negative Collection, it was important to first gain an understanding of Newhall's life and work. I therefore conducted research at George Eastman House Menschel Library and, online, at Ryerson University Library. The Menschel Library subject files contained Newhall's obituaries and several other relevant articles, published at the time of her death. Because her life was so closely linked with that of her husband, Beaumont Newhall, I also read through his file and found several interviews of interest.

I consulted the library catalogue and located a tribute to Nancy Newhall published in the year after her death. This document ${ }^{1}$ contained selections of some of Newhall's important writings about photography, a complete bibliography of her writings, and several pieces about her life, the importance of her work, and her contribution to the history of photography. It also featured examples of some of her photographic works rarely published or written about. A search of all relevant periodicals published near the time of Newhall's death yielded articles from Image ${ }^{2}$ and Exposure. ${ }^{3}$

I read Newhall's biography of Ansel Adams, ${ }^{4}$ her book on P.H. Emerson, ${ }^{5}$ and her collaboration with Paul Strand, A Time in New England. ${ }^{6}$ I also examined a volume of the letters of Ansel Adams containing a large number of letters between Adams and Newhall. ${ }^{7}$ Beaumont Newhall's autobiography, Focus, ${ }^{8}$ was a pivotal resource in establishing a chronology of Nancy Newhall's life. Several writings about Black Mountain College were examined, as well as online sources regarding the history and influence of the college.

A thorough online periodical search of databases and indices available through the Ryerson University Library yielded very little additional information, and no theses

\footnotetext{
${ }^{1}$ Beaumont Newhall and Peter Hunt Thompson, eds., Nancy Newhall 1908/1974 (San Francisco, Friends of Photography, 1974).

2 Patricia G Fuller, "Nancy Newhall (1908-1974)," Image (1974):1-5.

3 Jim Alinder, ed., "Nancy Newhall: 1908-1974," Exposure 12:3(1974):2-3.

${ }_{5}^{4}$ Nancy Newhall, Ansel Adams. Volume 1, The Eloquent Light (San Francisco, Sierra Club, 1963).

${ }^{5}$ Nancy Newhall, P.H. Emerson: The Fight for Photography as a Fine Art (New York, Aperture, 1975).

${ }^{6}$ Nancy Newhall, and Paul Strand, Time in New England (New York, Oxford University Press, 1950).

${ }^{7}$ Mary Streeet Alinder, and Andrea Gray Stillman, eds, Ansel Adams: Letters and Images 1916-1984 (Boston, Little Brown and Company, 1988).

${ }^{8}$ Beaumont Newhall, Focus: Memoirs of a Life in Photography (Boston, Little Brown and Company, 1993).
} 
or dissertations related to Nancy Newhall's life or work were found. During the scanning and cataloging process, I conducted further research on the individuals pictured in the negatives, including Anni Albers, Buckminster Fuller, Dorothy Norman, and Ansel Adams.

I attempted to reach Deborah Klochko to speak with her about Newhall. Klochko contacted the museum in 1999 stating she was interested in viewing the Newhall negatives in relation to a project on the historian. While there is no evidence her project was ever completed, I believed Klochko could be a further resource. She did not, however, respond to my inquiry. It was also suggested I contact Peter Bunnell since he was at George Eastman House at the same time as the Newhalls and had a close relationship with the couple. Unfortunately, he did not respond either. 


\section{Biography of Nancy Newhall}

Nancy Newhall was an accomplished writer, photographic historian, and photographer. She advocated for, and was friend to, many of the great photographers of the 20th Century--Ansel Adams, Alfred Steiglitz, Edward Weston, Brett Weston, Minor White, and Paul Strand were among her circle of close acquaintances. Her contributions to the field of photographic history include a collaborative work with Paul Strand, a biography of Ansel Adams, a book on the photographic art of P.H. Emerson, and her work as editor of Edward Weston's notebooks, Daybooks I and II. ${ }^{9}$ In addition, Newhall curated numerous photographic exhibitions, including the first Paul Strand and Edward Weston retrospectives at MoMA, and several exhibitions featuring the work of Ansel Adams.

Born Nancy Wynn Parker to Beulah and Herbert Parker on December 15, 1908 in Swampscott, Massachusetts, Parker spent her youth in Swampscott, Massachusetts, Portland, Maine, and Newburyport, Massachusetts. In 1930 she graduated from Smith College where her studies focused on creative writing, drama, and art, and she held the position of art editor of the Smith College Monthly. After graduating, she moved to New York City to study painting at the Art Students League and, in 1933, she had her first one-person exhibition of paintings at Grace Horne Galleries, Boston. ${ }^{10}$

During these early years in New York as a student at the Art Students League, Nancy Parker met Beaumont Newhall, a recent graduate of the Fogg Museum program at Harvard University, and the couple became engaged several years later in January 1935. Newhall had completed his studies and was working at the Philadelphia Museum of Art, where he led gallery tours and gave lectures on artists. He wanted, however, to wait until he had a steady and better paying job before getting married. After holding a similar position at the Metropolitan Museum of Art in New York City, Newhall decided to return to school to pursue doctoral studies. During their engagement, Parker spent time in New York City and then eventually moved to Marblehead, Massachusetts where she lived in an artist's studio and focused on her paintings. In November 1935 Beaumont Newhall

\footnotetext{
${ }^{9}$ Nancy Newhall, ed., The Daybooks of Edward Weston. Volume I, Mexico, and Volume II, California (Rochester, George Eastman House, 1961-63).

${ }^{10}$ Beaumont Newhall, Focus, p.49.
} 
took a position as librarian at MoMA and the couple married in Swampscott in July of the same year. ${ }^{11}$

Soon after Beaumont Newhall was hired at MoMA, the director of the museum, Alfred H. Barr, Jr., enlisted Newhall to curate a photography show at the museum. He was given a budget of $\$ 5000$ and, soon after the wedding, the newlyweds set off to Europe to honeymoon and to collect photographs for the exhibition. In Paris the couple met collector Victor Barthelemy and visited Paul Nadar at his studio. In London they met with László Moholy-Nagy and acquired prints for the exhibition. When they arrived home, perhaps because of this trip, and influenced by her husband's passion for photography, Nancy Newhall decided to abandon her career as a painter to pursue the study of photographic history. Nancy Newhall writes that she wanted to "give up painting, take up photography, to put my energies behind artists and causes I believe in."12

Over the next 30 years Nancy Newhall, alongside her husband, dedicated her life to the study of photography. She focused her research and energies on several photographers who she promoted tirelessly--Paul Strand, Edward Weston, and Ansel Adams. In 1939 the Newhalls met Ansel Adams while he was in New York City for the opening of the Museum's new building. This meeting was the start of a lifelong friendship between the Newhalls and Adams and would result in numerous collaborations between them. In the summer of 1940 Beaumont and Nancy Newhall traveled west for the first time. The couple visited Ansel Adams in San Francisco and accompanied Adams and his wife, Virginia, to Yosemite. Adams introduced them to Edward Weston and Weston's wife, Charis. Beaumont Newhall writes, "On that visit to the Weston's, Nancy and I looked at a great number of Edward's photographs and read much of his journal, or Daybook. Our visit led to the Weston retrospective exhibition of 262 photographs at the museum in 1946 which Nancy organized, and to the publication of his Daybooks in two volumes, which Nancy edited."13

In 1942 Beaumont Newhall was sent overseas to serve in World War II and, in his absence, Nancy Newhall was appointed MoMA's Acting Curator of Photography. Prior

\footnotetext{
${ }^{11}$ Susan Weilley, “A Conversation with Beaumont Newhall," ARTnews 83(1984): 88-98.

12 Patricia G Fuller, "Nancy Newhall (1908-1974)," Image (1974):1

${ }^{13}$ Beaumont Newhall, Focus, p. 65.
} 
to taking the position ${ }^{14}$ at MoMA, Nancy Newhall had worked for two years on a biography of Alfred Steiglitz, researching and spending countless hours with the photographer. She abandoned the project around the time she took over her husband's position at MoMA. During her time as Curator, Newhall planned and executed 15 exhibitions of photographs, including shows featuring Helen Levitt, Eliot Porter, W. Eugene Smith, Aaron Siskind, Harry Callahan, and Weegee. Diana E. Edkins, in her Tribute to Nancy Newhall, states, "Inexperienced in museum work and working against many obstacles, Nancy took on the enormous responsibilities of maintaining the department's functions, learning as she went along. She embraced photography with a great intensity" 15

The following year, Nancy Newhall opened a short-lived photography center at MoMA, the first such museum space dedicated to the continuous exhibition of photographs. In 1945 she curated and wrote the catalogue for a Paul Strand exhibition, and in 1946 she organized, curated and authored the catalogue for the Edward Weston Retrospective at MoMA. When Beaumont Newhall returned home from the war in 1946, Edward Steichen had been hired as director of the photography department at MoMA and controversy ensued over the direction the department would take. Amid rising tensions, Beaumont Newhall resigned from his position as curator in March 1946.

Nancy Newhall spent the next two years working with Paul Strand on their collaborative history of New England. Strand photographed while Newhall researched and gathered the text for the book from historical documents found in libraries and archives; the two efforts were finally combined to produce a "kind of New England autobiography." 16 The work, Time in New England, was published in 1950. Nancy Newhall was fascinated by the interaction of text and image and, as Patricia G. Fuller points out in her piece, Nancy Newhall (1908-1974), "She found a unique and sensitive integration of the two forms, in which neither illustrated the other, but together found a singular eloquence." 17 Time in New England is an important example of a photographic

\footnotetext{
${ }^{14}$ The interviews, notes, and writings from this project are part of the Beaumont and Nancy Newhall Papers at the Getty Research Institute.

${ }_{15}$ Diana E. Edkins, "A Tribute to Nancy Newhall," in Nancy Newhall 1908/1974, Beaumont Newhall, and Peter Hunt Thompson, eds., (San Francisco: The Friends of Photography, 1975) 2.

${ }^{16}$ Ibid.

${ }^{17}$ Fuller, Image,p. 3.
} 
book that seeks to marry image and text in this unique way; rather than text simply referring to or describing a specific photograph, the two forms worked together to create an experience more meaningful than that gained by viewing a picture or reading text on its own. The work remains a seminal volume in the development of the photographically illustrated book.

After Beaumont Newhall's resignation from MoMA, the couple spent several summers at Black Mountain College in North Carolina. Beaumont had met the artist Josef Albers while on a trip to Chicago, and Albers invited him to teach at a summer session at the innovative college. Opened in 1933, Black Mountain College was conceived as a new type of educational institution modeled on John Dewey's ideas of progressive education, and stressing the importance of the practice of art in a liberal education. Josef Albers was hired as the school's first art teacher. Albers, along with his artist wife Anni and many other luminaries (William and Elaine de Kooning, Robert Rauschenberg, Jacob Lawerence, Merce Cunningham, Kenneth Noland, and Buckminster Fuller), helped shape this extraordinary education institution. ${ }^{18}$ Beaumont Newhall taught at the school's 1946-summer session and was invited back in 1947 and 1948. Nancy Newhall accompanied her husband to these sessions and photographed many of the teachers and students at the college. These portraits, particularly the images of Anni Albers, show Nancy Newhall to be a sensitive and intuitive portrait artist; the formidable and engaging character of Albers shines through in the portraits.

In 1948 the Newhalls moved to Rochester, New York, when Beaumont Newhall accepted a position as curator of the soon-to-be-opened George Eastman House. During this time, the Newhalls collaborated with Minor White, Ansel Adams, Dorothea Lange and Barbara Morgan to found Aperture Magazine. ${ }^{19}$ By 1958 Beaumont had become Director of Eastman House and, for the next 13 years, the couple lived and worked in Rochester, New York. During this time their collecting trips to Europe brought them in contact with many eminent artists of the era, including Alvin Langdon Coburn, Brassai, Henri Cartier Bresson, and Man Ray. In 1962 Nancy Newhall wrote the introduction to an Eastman House publication, A Portfolio of Sixteen Photographs by Alvin Langdon

\footnotetext{
${ }^{18}$ Mary Emma Harris, The Arts at Black Mountain College (Cambridge, The MIT Press, 1987).

${ }^{19}$ Beaumont Newhall, Focus, p. 110.
} 
Coburn. ${ }^{20}$ She also curated several exhibitions at Eastman House but was unable to collaborate "officially" with her husband because of rules prohibiting spouses from working together at the museum. ${ }^{21}$

Shortly after moving to Rochester, Nancy Newhall began her extensive collaboration with Ansel Adams, and this important partnership and friendship resulted in many books, magazine articles and exhibitions over the years. Between 1944 and 1967, Nancy Newhall traveled west on 14 different occasions to work with Adams, and from 1950 to 1959 she spent a third of each year in California. As Beaumont Newhall describes in his autobiography, Focus, these trips took place in part because Nancy was unable to work at Eastman House as the couple had planned. Bored in Rochester and wanting to escape the harsh winters, she spent an increasing amount of time traveling and working with Adams. ${ }^{22}$ Both Nancy and Beaumont were friends with the photographer, but Nancy Newhall and Adams were particularly close, sharing similar outgoing personalities. Ansel Adam's wife, Virginia, in Beaumont Newhall: Colleagues and Friends, writes: "Beaumont, Nancy, Ansel and I were best friends...Nancy and Ansel were both extroverts, while Beaumont and I were shy. The four of us traveled many miles together, as Ansel and Nancy worked on their many joint projects together."23 Nancy Newhall's letters to Adams illustrate the nature of their friendship as she often refers playfully to Adams as "Beard" or "THEE.,"24 After Nancy Newhall's death in 1974, Ansel Adams wrote, "When I think of Nancy Newhall, I think of sunlight. Even on the drabbest day or enveloped with the occasional sour and empty moments of life, Nancy always triumphed over the environment and the mood. She had a compelling internal luminance which glowed in all her thoughts, her writings and her personality."25 26

\footnotetext{
${ }^{20}$ Nancy Newhall, A Portfolio of Sixteen Photographs by Alvin Langdon Coburn (Rochester, George Eastman House, 1962).

${ }^{21}$ Beaumont Newhall, Focus, p.245.

${ }^{22}$ Ibid, p. 245.

${ }^{23}$ Virginia Adams, "Beaumont Newhall," in Beaumont Newhall: Colleagues and Friends (Santa Fe, Museum of New Mexico, 1993).

${ }^{24}$ Nancy Newhall, "letter to Ansel Adams," in Ansel Adams: Letters and Images 1916-1984, Mary Streeet Alinder, and Andrea Gray Stillman, eds., (Boston, Little Brown and Company, 1988), 271.

${ }_{25}$ Ansel Adams, "Nancy Newhall," in Nancy Newhall 1908/1974, Beaumont Newhall, and Peter Hunt Thompson, eds., (San Francisco: The Friends of Photography, 1975), 43.

${ }^{26}$ Their complete correspondence, and the entirety of Nancy Newhall's work related to Adams, is held at The Center for Creative Photography in Tucson, Arizona.
} 
In 1955 Nancy Newhall assisted Ansel Adams with the exhibition This is the American Earth. Adams wanted to create an exhibition showing the power and beauty of the National Parks and the importance of conserving natural resources. In 1960 The Sierra Club published the work from the exhibition in book form. ${ }^{27}$ Newhall contributed the text for the publication, which differed dramatically from her earlier work with Paul Strand. While text for the Stand work was culled from historical documents, Newhall wrote the majority of this text in prose form in a rather dramatic style, much like Adam's photographs. This American Earth makes a powerful statement about man's negative impact on the earth and the beauty that must remain protected by the National Parks System. In 1963 Nancy Newhall curated the Ansel Adams retrospective at the deYoung Museum in San Francisco and wrote the catalogue for the exhibition. In the same year the first part of her biography of Adams, The Eloquent Light, was published. ${ }^{28}$

In 1971 Beaumont Newhall retired from George Eastman House and the couple moved to New Mexico where Nancy continued with the work she had started in Rochester on a monograph of the life and work of photographer P. H. Emerson. The book, completed shortly before her death in 1974, was published by Aperture in 1975 under the title, P. H. Emerson: The Fight for Photography as a Fine Art. She had planned to take up her long abandoned work on Alfred Steiglitz but, unfortunately, this project was never realized. Newhall was killed in a freak rafting accident while on vacation with her husband on the Snake River in the Grand Teton National Forest. Beaumont Newhall described his wife's death in Focus, "In the summer of 1974, Nancy and I vacationed in the Grand Teton National Park in Wyoming... On our last day we took a trip down the Snake River in a raft. Our guide and oarsman, while pointing out the natural features of the riverbank, told us the water was unusually high and was eroding the bank around the roots of a huge, overhanging tree. He said that someday that tree would fall. Suddenly, without warning, it fell across the raft on us. Nancy was struck down with such violence that she died a week later." 29

Nancy Newhall contributed significantly to the field of photographic history. She published over 80 articles and books on the subject and curated over 20 exhibitions.

\footnotetext{
${ }^{27}$ Ansel Adams, and Nancy Newhall, This is the American Earth, (San Francisco, Sierra Club, 1960).

${ }^{28}$ Nancy Newhall, Ansel Adams. Volume 1, The Eloquent Light,(San Francisco, Sierra Club, 1963).

${ }^{29}$ Beaumont Newhall, Focus, p.245.
} 
Newhall was friend and colleague to some of the great photographers of the 20th Century including Alfred Steiglitz, Ansel Adams, Alvin Langdon Coburn, Edward Weston, Minor White, and Paul Strand, and was an important advocate for their work. She was also a talented photographer in her own right and left behind a legacy that not only includes her writings but also an impressive photographic record of the places she visited and the people she knew. 


\section{Scope and Content of Collection}

The Nancy Newhall Negative Collection consists of 556 black and white negatives made between 1937 and 1963 . The collection contains a small number of color transparencies and only six $2 \frac{1}{4} \times 2 \frac{1}{4}$ black and white contact prints. Most negatives are $4 \times 5$ inch, with some $35 \mathrm{~mm}$ and $2 \frac{1}{4} \times 2 \frac{1 / 4}{4}$ inch negatives.

The majority of the negatives are portraits of prominent figures in the history of photography and the arts during Newhall's lifetime, including Ansel Adams, Beaumont Newhall, Brett Weston, Brassai, Margaret Bourke-White, Minor White, Buckminster Fuller, Anni Albers, Jacob Lawrence, and other lesser-known figures. The negatives were made throughout the United States, with the majority made in New York, New Mexico, Colorado, and California, and many images chronicle students, faculty, and scenery at Black Mountain College near Ashville, North Carolina. There are also over 100 landscape images, many of which were made in New England, California, and New Mexico.

\section{Provenance and Copyright}

The Estate of Beaumont Newhall gifted the Nancy Newhall Negative Collection to George Eastman House International Museum of Photography and Film in April 1995 as an unconditional gift.

The Donor gave George Eastman House the right to reproduce the images for research and educational use. The museum now holds a non-exclusive, non-commercial copyright to the collection. This agreement includes the Museum's right to include images in website presentations and other digital imaging applications. 


\section{Process}

At the outset of this project, the Nancy Newhall negatives were housed in an $11 \times 14$ photographic paper box in the Registrar's storage room at George Eastman House. The negatives were not accessioned but the collection had been inventoried at the time of its arrival at the museum in 1995. The inventory was thorough--each enclosure containing a negative or multiple negatives was identified with a number corresponding to an entry on the inventory list along with transcriptions of any information appearing on the enclosure. The number of negatives in each enclosure was also listed in the inventory.

The inventory and the data written on the enclosures was the only information that came with the collection. The general condition of the collection was good. Only a small percentage of the materials were housed in glassine enclosures, and perhaps because of good storage conditions, those negatives appeared to be in the same condition as ones stored in paper envelopes. The color material was shot on Kodachrome and was in good condition.

After a preliminary examination of the collection and inventory record, I gathered data on the life and writings of Newhall as outlined in the methodology section of this paper. This information provided a contextual framework from which to view the collection and allowed me to consider Newhall's work in relation to her life, her travels and the people she knew. I then began the physical arrangement, scanning, rehousing and cataloging of the negatives.

Objects accessioned into the museum's permanent collection are divided into lots. Therefore, the first step in the physical arrangement of the collection required a decision as to how the negatives were to be divided. For example, the number of lots and how the objects are distributed within each group is determined by the nature of the collection, its original arrangement, and many other relevant factors. The majority of the $4 \times 5$ inch negatives came to the museum housed in envelopes, many of which were inscribed by Nancy Newhall with date, place or subject and had codes such as BN (Beaumont Newhall), BMC (Black Mountain College), and AA (Ansel Adams). Because of this preexisting information, it was decided the arrangement of the collection should honor these 
subject divisions whenever possible. The $2 \frac{1 / 4}{4} 2 \frac{1 / 4}{4}$ and $35 \mathrm{~mm}$ negatives were grouped together in envelopes or sleeves and usually represented separate rolls of film.

With these standards in mind, the collection was divided into 19 lots. Newhall's subject codes were maintained in all instances except the following: landscape images were combined and then divided into 2 groups representing the Eastern and Western United States, and two other lots, "portraits" and "color works", were created outside the original subject codes. This information was given to the Registrar's office and the collection was assigned lot numbers as well as sub numbers corresponding to items within each lot. Because it is desirable to have this collection consecutively numbered, it was important to be certain of the arrangement before this step was implemented.

An issue with arrangement and numbering occurred during the preparation of portraits of Ansel Adams. An initial decision was made to group all portraits of Ansel Adams in one lot. However, once I began rehousing and scanning the portraits I realized that the storage requirements for the smaller format negatives would be different from the $4 \times 5$ negatives. This would require objects with consecutive accession numbers be housed in two different places, potentially complicating the tracking of objects. In order to accommodate this new arrangement, five additional lots were created by the Registrar's office.

After discussion with museum staff about policy regarding scanning of collections material it was determined that I would scan the negatives at a resolution high enough to produce an $8 \times 10$ print at $300 \mathrm{dpi}$. These files would then be reformatted to jpegs and added to the cataloging records I would eventually create in the collections management system. The original Tiff files would be copied onto DVD's and stored with the negatives. Handling of the negatives was also an issue as it was important to ensure that no damage occurred to the objects during scanning or rehousing. Wearing white gloves a small number of negatives at a time were carefully removed from their existing enclosures, dust was removed with a sable brush, and then the object was placed into the negative carrier. The scanning bed was carefully cleaned before each scan.

Once lots were determined and accession numbers assigned, I was able to start scanning and rehousing the objects. I began with the $4 \times 5$ negatives and worked systematically through the lots. The first lot consisted of ten Beaumont Newhall 
portraits. It was possible to scan four $4 \times 5$ negatives at one time. While the objects were scanning, I printed the corresponding accession number, the name "Nancy Newhall," and a brief subject description on the new enclosure (white, buffered, seamed envelopes). Once the objects were scanned, the files were given the accession number as a file name, and the objects were carefully placed in their corresponding enclosures and finally housed in clamshell lid negative storage boxes. The original enclosures were then scanned to preserve information appearing in Nancy Newhall's hand. These scans, both of the negative and enclosure, are now part of the museum's cataloging records. The scans were performed at high resolution, $800 \mathrm{dpi}$, to ensure quality and allow for varied use in the future, reducing the necessity of rescanning and unnecessary use of the objects, a source of potential damage. The scans were not color corrected or altered unless the negative was particularly thin or under-exposed, resulting in a dark or hard to read scan. These images were adjusted in Photoshop to make the scan readable.

Once negative scanning was completed, the negatives were cataloged and entered into the collections management system. Information entered into the record included dates and titles as inscribed by Newhall on the original enclosures and any other information (e.g. geographic place, generic subject matter, photographic process, trade name of photographic material, etc.) that could be determined. The digital images made from the negatives and enclosures were also attached to these records allowing researchers the ability to see the work of Nancy Newhall, an integral part of this project. 


\section{Conclusion}

Nancy Newhall was an important figure in Twentieth Century photographic history, making extensive contributions to the field during her lifetime. Tirelessly pursuing research and writing opportunities, she published extensively on the subject of photography, writing passionately and elegantly on the topic. She was advocate for, and friend to, many of the great photographers of her era. Nancy Newhall was also a photographer in her own right, capturing on film the people she met and the places she visited during her life.

Prior to completion of this project, the Newhall negatives at George Eastman House were neither arranged systematically nor cataloged, making viewing difficult, and decreasing the usefulness of the collection. Digitization and cataloging of the collection now provides researchers with ease of access to Nancy Newhall's work. In addition, thoughtful arrangement of the negatives (grouping images into coherent categories and preserving Newhall's original coding) has increased the collection's historical relevance, making it a valuable resource for those interested in investigating the life, photographs, and travels of Nancy Newhall and the important photographers with whom she associated. 
Appendix A-Chronology of Nancy Newhall's Life

December 15, 1908 - Nancy Wynn Parker born, Swampscott, Massachusetts; spends youth in Portland, Maine, and Newburyport, Massachusetts

1930 - Graduated Smith College; focused on art, writing and drama and was art editor for the Smith College Monthly; goes on to study painting at the Art Students League, New York City

1933-First one-person exhibition of paintings held at Grace Horne Galleries, Boston

January 1, 1933-Engaged to Beaumont Newhall

November 1, 1935-Beaumont Newhall starts work as librarian at Museum of Modern Art (MOMA)

May 1936 - Nancy Wynn Parker lives in studio in Marblehead, Massachusetts where she focused on her painting

July 1, 1936-Nancy Wynn Parker and Beaumont Newhall marry in Swampscott, Massachusetts

Fall 1936-Newhalls combine honeymoon and collecting trip to Europe, acquire works for Beaumont Newhall's upcoming exhibition on history of photography at MOMA (Photography 1938-1937); in Paris meet collector Victor Barthelemy and visit Paul Nadar at his studio; in London meet László Moholy-Nagy and acquire prints

March 17, 1937-Photography 1839-1937 opens at MOMA

May 10, 1939-New MoMA building opens on the site of old Rockefeller mansion at 11 West 53rd Street.

Spring 1939-Newhalls meet Ansel Adams in New York for opening of museum's new building

1940-1942 - Nancy Newhall works on biography of Alfred Steiglitz but eventually abandons project

Summer 1940 - Newhalls go west for first time; visit Ansel Adams in San Francisco and accompany him and wife Virginia to Yosemite; in San Francisco Adams introduces Newhalls to Edward Weston

Mid October 1940 - Ansel Adams arrives in New York to serve as Vice Chairman of Photography Committee for new Department of Photographs at MoMA and to assist 
Beaumont Newhall with Sixty Photographs exhibition opened December 1940

August 1942-Beaumont Newhall takes leave from museum to serve in WWII

August 1942-1945-Nancy Newhall Acting Curator of Photographs at MoMA; curates 15 exhibitions of artists including Helen Levitt, Eliot Porter, W. Eugene Smith, Aaron Siskind, Harry Callahan and Weegee

1944-1967-Nancy Newhall takes 14 extended trips west to collaborate with Ansel Adams; throughout the 1950's spends 4 months of each year in California

1944 -Nancy Newhall travels to Carmel to meet with Weston and choose prints for upcoming retrospective

May 23, 1944-Art in Progress opens at MoMA; Nancy Newhall selects 247 photographs for the exhibition; among large number of 19th century prints, also includes 20 photographs by Alfred Stieglitz, 26 by Edward Weston, 16 by Ansel Adams

1945-Newhalls visit the Westons in Carmel

April 25, 1945-Nancy Newhall curates Paul Strand Retrospective at MoMA; writes catalogue accompanying exhibition

Dec 10, 1945-Edward Steichen appointed Director of Photography Department at MoMA

1946-Newhalls and Paul Strand photograph in Mystic Seaport, Connecticut

March 7, 1946-Beaumont Newhall resigns from MoMA

Feb 1946- Nancy Newhall curates and writes catalogue for Edward Weston Retrospective, opens at MoMA

August 1946-Beaumont Newhall teaches at summer institute, Black Mountain College; invited by Josef Albers and is accompanied by Nancy; lectures on history and aesthetics of photography, topics including "The Tradition", "Photography in the Twentieth Century", and "Photographic Vision: An Approach to he Aesthetics of Photography"; Newhall invited to teach the following summer for full two-month session

June 1947- Newhalls join Ansel Adams on photography trip to Yosemite and The Grand Canyon

July, August 1947-Newhalls at Black Mountain College

June 21, 1948-Beaumont Newhall accepts job as Curator, George Eastman House 
July, August 1948-Newhalls at Black Mountain College

September 1, 1948-Newhalls move to Rochester, NY, Beaumont Newhall begins work at George Eastman House

November 9, 1949-George Eastman House opens to the public

1950 - Nancy Newhall/Paul Strand book, Time in New England, published

1950 -Nancy Newhall photographs Dorothy Norman, writer and friend of Alfred

Stieglitz and his eventual biographer

August 1950 - Newhalls vacation with Ansel and Virginia Adams and Edward and Charis Weston

1952-Aperture founded by Ansel Adams, Minor White, Dorothea Lange, Barbara Morgan, Beaumont and Nancy Newhall

Fall 1952-Newhalls go on collecting trip to Europe. Nancy Newhall meets with Alvin Langdon Coburn on commission by Modern Photography to write profile of the photographer (unpublished); visits Mathilda Teresa Talbot, granddaughter of William Henry Fox Talbot, at Lacock Abbey; visits Henri Cartier-Bresson and Man Ray in Paris

1954-Ansel Adams and Nancy Newhall collaborate on a photographic book on Death Valley

1955-Nancy Newhall and Adams curate the exhibit, "This Is the American Earth", at LeConte Memorial Lodge in Yosemite; exhibition then travels throughout the United States, venues include the Smithsonian, MoMA, and the California Academy of Science

1958 - Beaumont Newhall appointed Director of George Eastman House

1960-This is the American Earth published-Ansel Adams' photographs and others accompanied by Nancy Newhall's epic prose

1963 - Eloquent Light published-Nancy Newhall biography of Ansel Adams illustrated with Adams' photographs; Nancy Newhall curates "The Eloquent Light", a retrospective of Adams work at the de Young Museum, San Francisco

1967-Newhalls and Ansel Adams begin 12-day summer photography workshop, UC Santa Cruz, annual until 1971; Nancy Newhall teaches picture editing and editing the photo essay

1971-Beaumont Newhall retires from George Eastman House 
1971-Beaumont Newhall accepts position as visiting professor of art, University of New Mexico, and moves to Albuquerque with Nancy in same year

July 7, 1974-Nancy Newhall dies in Jackson, Wyoming. 


\section{Appendix B-Nancy Newhall Resources}

1. The Center for Creative Photography, Tucson, Arizona (CCP)

Beaumont and Nancy Newhall Collection-holds correspondence, writings, and subject files, 1930-1983 in relation to the careers of the couple. The bulk of the collection contains incoming letters from Ansel Adams and Edward Weston, and published and unpublished manuscripts on Ansel Adams. CCP also holds 9 photographic prints made by Nancy Newhall.

\section{The Getty Research Institute (GRI)}

Beaumont and Nancy Newhall Papers, 1843-1993, bulk 1929-1993-The bulk of this collection relates to the life of Beaumont Newhall, but there is also a significant amount of Nancy Newhall's writings, letters, journals, and subject files. The extensive work she did on the life and art of Alfred Steiglitz is in this collection. The GRI also has a small selection of photographs and paintings made by Nancy Newhall.

\section{MoMA}

Nancy Newhall and Edward Weston Correspondence-Original Correspondence between Nancy Newhall and Edward Weston. Photocopies of these letters can be found in the Nancy Newhall Collection at CCP.

\section{Scheinbaum \& Russek, Fine art Photography Dealers}

Nancy Newhall Prints - David Sheinbaum is the copyright administrator for the estate of Beaumont Newhall. The dealer made a significant number of prints from the Nancy Newhall and Beaumont Newhall negatives before they were given to Eastman House. Many of these prints can be seen on their website and purchased from the dealer.

\section{George Eastman House (GEH)}

Nancy Newhall Negative Collection, Beaumont Newhall Negative Collection, and Nancy Newhall-Paul Strand Correspondence-GEH has significant resources for researchers including the negatives of Beaumont and Nancy Newhall, and letters between Nancy Newhall and Paul Strand. 


\section{References}

Adams, Ansel, and Nancy Newhall. This is the American Earth. San Francisco: The Sierra Club, 1960.

Alinder, Jim, ed. 'Nancy Newhall: 1908-1974." Exposure 12:3(1974): 2-3.

Alinder, Mary Street, and Andrea Gray Stillman, eds. Ansel Adams: Letters and Images 1916-1984. Boston: Little Brown and Company, 1988.

Fuller, Patricia G. "Nancy Newhall (1908-1974)." Image (1974): 1-5.

Harris, Mary Emma. The Arts at Black Mountain College. Cambridge: The MIT Press, 1987

Newhall, Beaumont. Focus: Memoirs of a Life in Photography. Boston: Little Brown and Company, 1993.

Beaumont Newhall: Colleagues and Friends. Santa Fe: Museum of New Mexico, 1993.

Newhall, Beaumont, and Peter Hunt Thompson, eds. Nancy Newhall 1908/1974. San Francisco: The Friends of Photography, 1975.

Newhall, Nancy, and Paul Strand. Time in New England. New York: Oxford University Press, 1950.

Newhall, Nancy. "The Need for Research in Photography." College Art Journal 4:4(1945): 203-206.

-----. P.H. Emerson: The Fight for Photography as a Fine Art. New York: Aperture, 1975.

----. A Portfolio of Sixteen Photographs by Alvin Langdon Coburn. Rochester: George Eastman House, 1962.

----. Ansel Adams. Volume 1, The Eloquent Light. San Francisco: Sierra Club, 1963.

Rule, Amy, and Nancy Solomon, eds. Original Sources: Art and Archives at the Center for Creative Photography. Tucson: The Center for Creative Photography, 2002.

Weilley, Susan. “A Conversation with Beaumont Newhall.” ARTnews 83(1984): 88-98. 
